\title{
TRANSFORMATIONAL CHANGE IN THE SOUTH AFRICAN GAMBLING AND LOTTERIES SECTOR
}

\author{
D Van Lill, Faculty of Management Sciences, Central University of Technology, South Africa
}

\begin{abstract}
Purpose: This paper examines the transformation of the South African gaming and casino sub-sector after South Africa's democratic dispensation in 1994 and the National Gambling Act (33 of 1996). These developments introduced an adapt-ordie scenario to the gambling and lotteries sector leading to a total overhaul of strategy, structure, systems, processes, technology, work, culture, behaviour and mindset. More specifically, Sun International's gaming and casino division's response to transformational change was examined by tapping into, and reflecting on, the experiences of managers involved in day-to-day casino operations.
\end{abstract}

Design: The conceptual framework of the research is based on transformation as a form of change where business principles and people management are highly integrated. Subsequently, a user-friendly tool called the "See-Saw model" was developed to measure transformational progress. The model was applied in six change management workshops for casino managers and, from this framework, transformational progress was interpreted.

Findings: The results highlighted the magnitude of change in the gambling and lotteries sector. It appeared that this sector has evolved in 10 year cycles up to 2000, whereas the current level of competitiveness fuels the demand for innovation and change in less than two year cycles. The second significant finding revolved around employees' perception that Sun International's gaming and casinos division has performed well in terms of value innovation variables.

Implications: The study confirmed that, in successful transformation, business innovation needs to be balanced by fairness principles. Moreover, that the threat-rigidity in leader and employee mindset has become a most challenging people management puzzle to position in securing sustainable competitive advantage.

Originality: The value of the research lies in the development of a user-friendly, non-threatening strategic tool called the "see-saw model" which can be used across industries to evaluate transformational progress from the employees' point of view.

Key words and phrases: South African tourism, change management, transformation, casino management, mindset.

\section{INTRODUCTION}

Since the advent of South Africa's democratic dispensation, leaders in the South African tourism industry have continuously found themselves in the white-waters of change brought about by the pressure of globalised business and local societal expectations. The gambling and lotteries sector exemplifies such dynamic and turbulent change, particularly within its largest segment, the casino sub-sector (THETA, 2003:21). During 2004, informal exchanges with gaming and casino executives of Sun International, the most significant South African tourism and leisure group, revolved around the challenges of daily casino management. Here, managing the continuous demand for change and innovation together with the contrasting human preference for stability and predictability emerged as a dominant challenge. While the market leadership of Sun International's gaming and casinos division is acknowledged as a remarkable strategic achievement, leaders' concern was whether the division had transformed sufficiently to maintain its market performance. Consequently, the need to determine the strengths and weaknesses of Sun International's gaming and casinos division in the context of the South African gambling and lotteries sector was recognised.

This study examines the change dynamic within Sun International's gaming and casinos division according to an appropriate change model. The research sets out by describing the role of casinos in general and more specifically the role of Sun International's gaming and casino division in the South African tourism industry. Subsequently, Sun International's challenge to evaluate its transformational 
progress in order to stay a major competitor in the casino market is linked to the theory of transformational dynamics. In consequence, the need for a systematic analysis is outlined and then supported by the development of a user-friendly tool called the "See-Saw Model". This measuring instrument was used as a workshop tool to extract salient information from casino management responsible for day-to-day operations. The last section of this paper reflects on the balance between business innovation and fairness principles and indicates areas to streamline transformational efforts.

\section{THEORETICAL BACKGROUND}

\section{The Role of Casinos in South African Tourism}

The prognosis for South African tourism and leisure remains favourable with growth increasing by more than 100\% since 1994 and reaching a record high of 7.4 million arrivals in 2005 (South African Tourism, 2006). In reviewing the direction of casino tourism in South Africa, Rogerson (2004:161) notes that casino gambling is often considered as a catalyst in the development of a tourism industry, providing new revenues, employment and visitors. The review concludes that "the role of casinos as a focal point for domestic tourism has decreased in post-apartheid South Africa, and casinos are now recognised as vehicles for Black Economic Empowerment (BEE) within South Africa's tourism economy" (Rogerson, 2004:178). The fact is that casino developments since 1994 have accounted for a R11.7 billion capital investment in the tourism industry (Rogerson, 2004), while the impact of gambling and lotteries is estimated at $0.38 \%$ of the domestic GDP, its economic multiplier effect is calculated at 3.00 (National Gambling Board of South Africa, 2003), and R1.7 billion was contributed in taxes in 2004 (Casino City Times, 2006).

Sun International operates within the southern African tourism industry, and more specifically within the gambling and lotteries sector (THETA, 2003:6). In 2005, the group was recognised as Africa's most significant tourism and leisure group, as reflected in their domestic market share of 42\% (Matthews, 2004) and group revenue reported at R5.14 billion. The group employs 8000 people and has created a further 50000 new employment opportunities in the broader southern African tourism industry (Sun International Group Profile, 2006). The group has also invested over R10 billion in new tourism infrastructure since the mid-1970s and contributed R406 million in taxes in 2005 (Sun International Annual Report, 2005). In 2005, Sun International's gaming and casinos division grew by $18 \%$ on 2004 and contributed $75 \%$ of the group revenue when compared to accommodation (12\%) and food and beverages (8\%) (Bacon, 2005).

\section{Managing Change in Sun International's Gaming and Casino Division}

During 2004, informal exchanges with Sun International gaming and casino executives about change challenges revealed that difficulties were not necessarily related to a lack of vision, but rather by the fact that the puzzles of the change process are often difficult to figure out and manage. These views reminded of the concept of blurring which Davis and Meyer (1998:7) defined as people having to cope with "something enormous happening all around, enough to make you feel that you are loosing balance and seeing double". Managers also identified the need to review the strengths and weaknesses of their organisation's change dynamic in order to maintain their standing in the gambling and lotteries sector.

These change challenges are certainly not unique to Sun International's gaming and casino division. Day and Halpin (2004:8) note that "unprecedented unpredictability and uncertainty occurs over all industries and organisational domains" - an opinion echoed by several scholars in the field of organisational development (Dess \& Pickens, 2000; Hamel, 2001; Anderson \& Ackerman-Anderson, 2001 and Grulke, 2001). While a steady flow of change management research presents new theories and models, it is concerning to note that less than 10 percent of top leaders in global organisations rate their organisation's record of change management as having been successful as organisational leaders struggle with the pragmatic aspects of leading change (Karp, 2006:4). The key question remains how this gap can be bridged. 
In an editorial review of the Journal of Change Management, Colin Carnall (2006:2) points out that the focus of change management is moving towards how people make sense of, and navigate in order to perform in changed organisational settings. Most recent publications in the field of change management substantiated this view in moving beyond the structure in change models towards an understanding of the roles that people play in managing successful change (Styhre \& Kohn, 2006; Smid, Van Hout \& Burger, 2006; Hull \& Lio, 2006 and Sminia \& Van Nistelrooij, 2006). This line of thought is also presented by Karp (2006), stating that organisational leaders should take account of chaos and use a systematic view when changing their organisations. Karp (2006) also strengthens his argument by examining the DNA of change leadership, more specifically the role of intra- and interpersonal leader expertise in setting a grand vision and leading network of people towards corporate achievement (Karp, 2006:9-12). Holden (2006:24-25) differentiated between successful change managers who have grown resilient and flexible through hardship, and less successful change managers marked by a cautious and vigilant approach to change threats. Holden (2006) argues that the best way to adapt to a continuously changing business environment centres on organisations' dedication to face the brutal realities of their external and internal environments. Successfully lead organisations open themselves to learning, as opposed to defending outdated behaviour and strategies. Holden (2006:30) also concludes that efficient change leadership is based on "side-stepping our own arrogance when we acknowledge and invoke forces beyond our own personality and bring them to bear on our lives, our work, our relationships, and the impact we wish to make with our lives".

In refining the systematic analysis of change dynamics, Anderson and Ackerman-Anderson (2001:31) define the three most prevalent types of change occurring in organisations as: developmental change; transitional change; and transformational change. Developmental change represents the improvement of an existing skill or performance standard to meet future needs. Transitional change occurs when an organisation adapts its business operations to a market requirement, for example by installing new technology and restructuring to maximise cost benefits. Transformational change is the most complex form and emanates from an adapt-or-die scenario, with the final destination being unknown. Transformational change is mostly catalysed by globalisation, diversity, informationalism and networks (Hamel, 2001) in the sense that customers are now better informed than ever before and they vote with their wallets (Grulke, 2001). What is known about transformational change is that a total overhaul of strategy, structure, systems, processes, technology, work, culture, behaviour, and mindset will be required. An example of transformation in South African tourism would be the diversification of the hospitality sector since 1990. Here, luxury accommodation changed from the average 234-roomed hotels in 1990 to 126-roomed units in 2005 in attending to high-paying, discerning guests whereas economical accommodation has grown from an average of 18 to 61-roomed units to capitalise on economies of scale (Grimsell, 2005). As far as the gambling and lotteries sector is concerned, competition shifted from two dominant mega-resort casinos in the former homelands to 40 smaller casinos throughout South Africa. In addition, Goldman (2000:30) mentions that transformation in South Africa is commonly perceived as deracialisation and achieving an ethnic mix, matching the country's demography that relates to casinos being used to strategise the achievement of BEE objectives. Hence it seems that the change dynamics presented in the day-to-day operations of South African casinos fall within the Anderson and Ackerman-Anderson (2001) definition of transformational change.

\section{Analysing the Transformation of Sun International's Gaming and Casino Division}

In contemplating how to analyse transformational change within Sun International, valuable guidelines were drawn from Mark Palmer's analysis of the internationalisation experiences of Tesco. In this study, Palmer (2005) posed three critical questions to extract the salient change management lessons: 1) What are the variables contained in this experience?; 2) What lessons can be drawn from these experiences?; and 3) How does this experience shape or inform the company's decision-making process? A conceptual model to analyse transformational change variables within Sun International's gaming and casino division can be drawn from the "drivers of change" model devised by Anderson and Ackerman-Anderson (2001:16-18). Their model portrays a sequence of seven change triggers, with each driver calling forth a change response in the next driver. These seven drivers (and their respective descriptors) are: 
1. Environmental trends. (Consideration of the remote environmental factors within which organisations and people operate. Typically, factors include political, economic, ecological, social and technological drivers.)

2. Marketplace requirements for success. (The aggregate set of customer requirements that determine what it takes for a business to succeed in its marketplace and to meet its customers' needs.)

3. Business imperatives. (Formalising the organisation's strategic response in meeting its customers' changing requirements.)

4. Organisational imperatives. (Adapting the organisation's structure, systems, processes, technology, resources, skills base, and staffing to achieve its strategic response.)

5. Cultural imperatives. (Adapting the organisation's culture to a collective way of being that will support the organisation's new design, operations and strategy.)

6. Leader and employee behaviour. (Defining the leaders' and employees' behaviour required to implement and sustain the new organisational design, and implementing initiatives to promote the required behaviour.)

7. Leader and employee mindset. (Enhancing the level of self-awareness of employees to enable them to understand that each employee has a unique worldview, assumptions and beliefs that cause them to behave and act as they do. Also to improve the ability of employees not to feel threatened by differences, but rather to see them as opportunities to get the team to perform better.)

The first four drivers depicting external and impersonal factors (environment, marketplace, organisations) are most familiar and have been collectively referred to as "value innovation" (Kim \& Mauborgne, 2003). The last three drivers present a relatively new edge to change dynamics in presenting what is internal and personal (culture and people), or which Kim and Mauborgne (2003) collectively regard as "fairness principles". Keeping this in mind, two elements were integrated in constructing a transformational change model to analyse Sun International's change dynamic, namely the set of transformational change drivers defined by Anderson and Ackerman-Anderson (2001) brought together with the need to balance value innovation and fairness principles. The validity of this reasoning is confirmed by Hersey and Blanchard (1993) who termed the ability to combine a global business perspective with social and interpersonal skills as transformational leadership. Anderson and Ackerman-Anderson (2001:16) argue similarly that many of the current struggles with transformation are the result of leaders not attending meaningfully to the cultural, behavioural and mindset components of transformation.

\section{RESEARCH OBJECTIVE}

\section{Conceptualising the Purpose of the Investigation}

The primary objective of this study is to examine the change dynamic within Sun International's gaming and casino division. To this purpose, the first secondary objective was to design a measuring instrument to examine the change dynamic based on the Anderson and Ackerman-Anderson (2001) model of transformational change. The secondary research objective was to measure employees' perceptions of change in Sun International's gaming and casinos division through a process of reflective engagement.

\section{Research Hypothesis}

Based on the research objective, the hypothesis tested in this study was that Sun International's gaming and casino division responded equally to all seven drivers of transformational change. 


\section{RESEARCH METHODOLOGY}

\section{Converting the Conceptual Model into a Measuring Instrument}

The review of change within the South African gambling and lotteries sector centred on transformation as a form of change that integrates business principles and people management. Subsequently, this concept was converted into a user-friendly tool called the "see-saw" model (Figure 1) to measure participants' perception of transformational change in a workshop setting.

Figure 1: The See-Saw Model

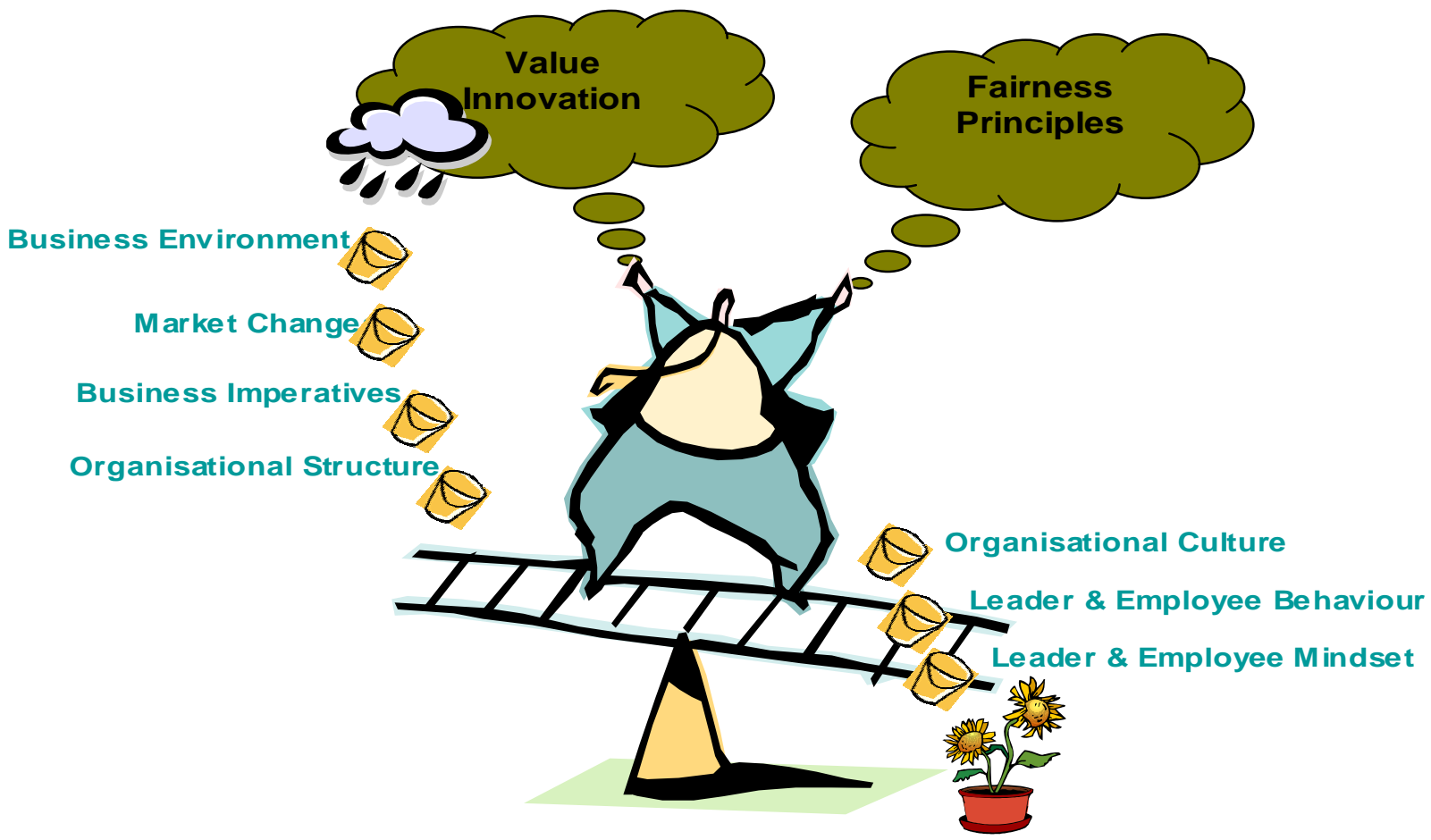

In this metaphor, a figurine balances a see-saw with seven buckets on its beams, with the weight slightly towards the right. The figurine represents an organisational leader balancing the change dynamics in his or her organisation. The four buckets on the left beam represent the four transformational change drivers associated with value innovation, namely the business environment, market needs, business imperatives, and organisational structure. The three buckets on the right beam represent the three drivers associated with fairness principles, namely organisational culture, leader and employee behaviour, and leader and employee mindset. The rainstorm, representing transformational change stimuli, pours into the first bucket of change, namely the business environment. Having filled the first bucket, the water cascades into the next bucket representing "market changes", and so on. Eventually, the last bucket, representing "change in leader and mindset", overflows onto the houseplant, which then flowers. The sequence in which the buckets fill and overflow represent the sequence in which these change drivers need to be attended to. The flowering houseplant represents the positive end-results achieved by appropriately transformed organisations.

The see-saw model was designed as an applied learning element in change management workshops comprising five learning elements: 1) The nature of transformational change; 2) Organisational symptoms when change is improperly managed; 3) How the information age drives change at the individual, 
company and macro-economic level; 4) How change affects team and leader dynamics; and 5) Using the see-saw model to manage change. In introducing the see-saw model, workshop participants are told that the purpose of the 30-minute exercise is to find out how they feel about the changes affecting their organisation. It is also intended to determine how they feel about their organisation's response to these challenges. Participants are then asked to narrow their perceptions to their working environments. Subsequently, a self-administered questionnaire containing descriptions of the seven transformational change drivers is handed out. Participants are asked to reflect on the information, to note comparable experiences for each driver, and to answer two questions on each driver. To this purpose, semantic differential scales are used, since the workshop aims to equip participants with the knowledge and skill to reflect on the polar dynamics associated with change management. In addition, this type of questionnaire is known to provide reliable results with people from all walks of life and different cultures (McDougall \& Munro, 1994). In rating the perception of, for example, the stimulus caused by environmental change, the first question was: "Over the last year, the impact of environmental change on [name of the organisation] was..." In rating the firm's response to environmental change, the second question was: "Over the last year, [name of the organisation] response to environmental change was..." For both questions, the bipolar scale is defined by the negative anchor "Not worth mentioning" on the left and the positive anchor "Formidable" on the right. For both questions, the directionality of the response is measured on a fivepoint scale that varies between "strongly agree (-2)", "magree (-1)", "neutral (0)", "agree (1) $\Rightarrow$ " and "strongly agree (2) $\Rightarrow$ ". The see-saw model was piloted on 18 BTech students enrolled at the Central University of Technology, Free State School of Tourism, Hospitality and Sport in 2004. As part of the module on change management, students were asked to complete the draft questionnaire in view of their company-based learning experiences in their third year, after which suggestions on comprehension and readability were incorporated.

\section{The Sample Framework}

From November 2004 to December 2005, six on-site workshops on change management titled "Beyond the Obvious" were presented at Sun International's Boardwalk, Meropa, Carnival City, Carousel and Sibaya Casino and Entertainment Worlds. A total of 50 employees in the gaming and casinos division participated, leading to 700 responses on the various drivers of transformational change. Of these, 23 (46\%) were general or first-line casino managers, 26 (52\%) held supervisory positions, and one participant was a personal assistant. White males comprised $36 \%$ of all participants, with $10 \%$ white females, $34 \%$ black males and $20 \%$ black females. Senior managers were grouped in workshops at the Meropa and Carousel casinos. Other participants were nominated from the Slots Accelerated Management Programme and were employed at the Boardwalk, Carnival City, Flamingo, GrandWest, Morula, Sibaya, Wild Coast Sun, and Sun City casinos. Workshop participants were restricted to ten per workshop to optimise discussion.

\section{Statistical Analysis}

Workshop venue, participants' positions in the organisation (management, supervisors) and the "seesaw" model were treated as independent variables in preparing the statistical analysis. Differences between the change stimulus and company response for the respective entries were noted as GAP, which was treated as the dependant variable. All statistical analyses were performed using the STATISTICA Release 6.0 (2002) statistical analysis package.

\section{Other Sources of Information}

The interpretation of the seven transformational change drivers was supported by two sources of information on change in the South African gambling and lotteries sector. The first included paper and web-based publications, desk-top reviews of published documents and policy, scholarly output, as well as company and other regulatory reports. The second source involved personal notes on conversations with Sun International leaders representing organisational development, as well as gaming directors, training directors, general managers of casinos and their first-line managers, training managers and workshop participants. In describing environmental trends, the stages of the sector's evolution from 1970 to 2006 
were outlined using the analysis described by Pearce and Robinson (2000:215-216). Information prior to 1970 , the views of operative staff, and information unavailable to the public were excluded from this report.

\section{RESULTS AND DISCUSSION}

The analysis focuses on GAP, which is the difference between a particular transformational stimulus and the division's response. In the first step of the data analysis, homogeneity in GAP variance was verified with Levene's test. Subsequently, the degree to which the three independent experimental variables influenced participants' views on transformational progress was determined. Here, significant relationships $(p<0.01)$ between GAP and managerial status $(r=0.20)$, workshop venue $(r=0.24)$ and transformational change drivers $(r=0.37)$ confirmed that the impact of the independent variables should be presented separately. Participants from the Slots Accelerated Management Programme (SAMP) perceived a significantly lower GAP (mean $=0.38$ ) when compared to senior managers (mean $=0.72$ ). This is probably related to the SAMP, which regularly exposes participants to change management initiatives across casinos. GAP differences between workshops contrasted the Boardwalk group (mean = 0.02) against the Sibaya group (mean $=0.71$ ). Based on participants' observations, the difference was related to leaders' approach to scouting for opportunities to add the personal touch. The differences between the seven transformational change drivers were most evident $\left(F_{6,338}=17.82, p<0.001\right)$ indicating that the hypothesis could be rejected. Subsequently, the differences in responsiveness were examined by means of Tukey's HSD test to perform a pair-wise GAP comparison for the seven transformational drivers. The results showed that the GAP between change stimulus and response for Environment, Business Imperatives and Organisational Imperatives (mean < 0.34) were inconsequential. The GAP observed for Marketplace Requirements, Cultural Imperatives and Leader \& Employee Behaviour ranged between 0.48 and 0.74 and showed that responsiveness to these change drivers could be improved, whereas the GAP for Leader \& Employee Mindset was most pronounced. Consequently, each of the seven transformation change drivers is discussed below.

\section{Environmental Trends}

The mean impact of environmental (external) influences was rated at 1.18, while the responsiveness of Sun International's gaming and casinos division was rated at 0.90 . The difference (GAP) of 0.28 reflected that managers felt that the division transformed sufficiently in response to this change driver. Further examination of environmental change showed that, in the 1970s, the Gambling Act of 1965 prohibited all forms of gambling in South Africa, except horseracing. The domestic gambling market provided limited opportunities, and boycotts and socio-political isolation limited foreign tourist numbers even further. Casino gambling, however, continued through major developments in the homelands, which were selfgoverning areas reserved for ethnic groups during the apartheid era. In 1979, Southern Sun, a company founded by Sol Kerzner in partnership with SA Breweries, opened Sun City, the first mega-resort casino development. At that stage, most casino operating skills were imported, since local staff development programmes were not considered a viable option. Remuneration to South Africans was poor and as a result staff turnover was high (THETA, 2003:82-83). In 1983 Sol Kerzner sold his shares in Southern Sun and founded Sun International South Africa (SISA) focusing on casino resorting. Over the next decade Kerzner negotiated a series of highly informal deals with homeland leaders in terms of which SISA acquired all 18 homeland casino licences. Apparently, Kerzner agreed to a high taxation rate on casino profits and secured the opportunity to self-regulate operations based on his partners' lack of capital and skill in auditing casino operations (Sallaz, 2003).

By the early 1990s, betting agencies began to operate in the former homelands under joint ventures. The gaming industry expanded sizeably and illegal operations began to impact on the market. In South Africa, horseracing remained largely a white activity, although black middle-class participation increased (THETA, 2003:84). During that period, SISA bought into a new company and became Kersaf Investments Limited ("Kersaf"), the holding company of Sun International. The rationale behind this move was to enable the construction and opening in 1992 of the Lost City, a mega-leisure complex based on the theme of a legendary lost African city. With the emergence of mega-resort casino developments such as 
Sun City and the Lost City as significant tourism nodes, casino training increased. More local employees filled positions previously taken by ex-patriots, and the first female supervisors and black male table operators were employed. Training in this era was mostly task oriented and non-portable (THETA, 2003:85). After the Lost City's completion, Kerzner gradually withdrew from local operations and founded a New York-listed company, Sun International Hotels $(\mathrm{SIH})$, which he has since grown into an international empire. With the new political dispensation in 1994, the former homelands were reincorporated into South Africa. This forced a policy decision on gambling either being illegalised or regulated. Consequently, the Lotteries and Gambling Board was established in terms of the Lotteries and Gambling Board Act and tasked to furnish recommendations for a national policy on all forms of gambling and lotteries. A significant board recommendation was for central government to accept responsibility for regulating and co-ordinating the sector through uniform laws and standards. The Lotteries and Gambling Board was dissolved in 1995 after submitting its final report (THETA, 2003:83).

In 1995, Kerzner resigned from SISA, with Kersaf retaining 44\% of SISA and $21 \%$ of SIH. In 1996, the National Gambling Act (33 of 1996) and Provincial Gambling Acts came into law. The national constitution provides that all matters relevant to casinos, racing, gambling and wagering, excluding sports pools, shall be legislated upon by both the provincial and the national government. Consequently, each province has its own Gambling Act with norms and standards set by the National Gambling Act. Subsequently, the National Gambling Board (NGB) was established in April 1997 under the National Gambling Act (33 of 1996) and mandated to regulate and co-ordinate the sector and to promote uniform norms and standards throughout South Africa. The NGB started operating in 1999, after all the provincial boards had been established. A major factor affecting the sector's business environment was Section 13 of the National Gambling Act (33 of 1996), which provided for the issuing of 40 licences throughout South Africa. These were distributed to Gauteng (six), KwaZulu-Natal (five), Mpumalanga (four), Northern Cape (three), Western Cape (five), Eastern Cape (five), Limpopo Province (three), North West (five), and the Free State (four). This created substantial diversification in the sector, as SISA was required to relinquish its monopoly and to divest itself of some of its operations. Similarly, Section 13 obliged all government bodies to dispose of their shareholding in the sector, causing the Northwest Development Corporation to transfer its shares to Sun Air Limited, a subsidiary of Kersaf.

The new millennium saw a surge of casino developments - such that the growth recorded in total investment in South Africa's tourism economy has been strongly driven by casino gambling (Rogerson, 2004). Despite the optimistic long-term view, business in 2001 was not that easy. The decline in tourism and downward pressure on disposable income, combined with increased levels of competition, had a negative effect on the market. In addition, the sector became plagued with illegal entrants such as "fafee" in the townships and illegal slot machines in KwaZulu-Natal. At that stage, Sun International had to honour capital commitments to the value of R1.3 billion. Boardwalk Casino operations came in below expectations, and Carnival City revenues were directly affected by the opening of new casinos in Kempton Park and Fourways. These results spooked the market, and Sun International's share price retired over 30\% from July to September 2001 (Radebe, 2001). Tough times, however, tend to foster collaboration, and strategic partnerships and mergers emerged, indicating that casino operations were about to centralise. In 2001, Kersaf announced a deal with Kerzner's SIH, in which Kersaf purchased the worldwide rights to the brand name Sun International. In 2003, the merger between the holding company Kersaf Investments Limited (62\% of shares), Sun Air Limited, SISA and Sun International (SA) Holdings (Pty) Ltd was approved (Competition Tribunal Republic of South Africa, 2003) and announced as a single listing, namely Sun International Limited (Matthews, 2004). The market diversified further with the closing of the KwaZulu-Natal lottery and introduction of the national lottery and the first bingo gaming in Gauteng (THETA, 2003:83). At this point, the lotteries and gambling sector accommodated about 850 employers (THETA, 2003:31) and 34570 employees through direct and induced employment (National Gambling Board of South Africa, 2003) - thus accounting for about 5.8\% of the estimated 600000 employees found in the South African tourism industry (THETA, 2003:28). For every 100 jobs created in the sector, a further 215 jobs were created in the rest of the economy.

By 2004, the tight regulation of betting and gambling operations had levelled the playing field. The National Gambling Act (33 of 1996) was repealed and the new National Gambling Act (7 of 2004) was 
signed into law. The new legislation provided for the overview of matters relating to casinos, gambling, betting and wagering, and promoted uniform norms and standards in relation to gambling throughout South Africa. Bacon (2005) notes that the legislative environment regulating the sector "has achieved noteworthy levels of maturity and sophistication, which augurs well for operators and regulators alike". As a typical response to a maturing market, the sector evolved towards exceeding customer expectations. This period is marked by the introduction of smartcard technology and increasing emphasis on the quality of the front-line staff and customer interface during 24-hour casino operations. Casino managers also had to address the significant increase in the demand for black administrative and support staff, as well as the poaching of especially experienced technicians. In response, training became vigorously employee centred, job specific, and aligned to the National Qualifications Framework. In addition, corporate governance principles became more pronounced and social responsibility issues more apparent in conditions of employment and training. Currently, in 2006, the gambling and lotteries sector has matured. Rivals are now continuously changing and restructuring to gain their share of the higher disposable income arising from lower interest rates and increased consumer confidence. Other substitutes affecting profitability include the weekly national lottery, more standardised regulations as government requires ever larger slices of leisure spend, and internet gambling. In addition, 50000 limited-payout machines might be introduced into taverns, clubs and shebeens, while the number of bingo venue licences might increase from eight to 300 in an effort to promote job creation (THETA, 2003: 86).

\section{Marketplace Requirements for Success}

The mean impact of change in market requirements was rated at 1.28, while the responsiveness of Sun International's gaming and casinos division was rated at 0.76 . The difference (GAP) of 0.52 reflected that managers agreed that the division could improve its response to changing client needs. Of interest is to note the strong strategic leadership of top management and the observation of casino managers that the competitive edge can be further strengthened by tapping into the wealth of experience of front line employees. In reflecting on Sun International's 2005 group revenue at R5.1 billion and approximately 40 000 daily customers (Sun International Group Profile, 2006), Chief Executive Peter Bacon stated that "the group has established itself as a successful leisure group offering superior gaming, hotel and entertainment experiences, exceeding their customers' expectations and their competitors' offerings". According to Bacon (2005), casinos, luxury hotels and resorts are branded in terms of experience, theming, and the mix of entertainment options on offer at each property to capture the public's imagination. Well-known hotel properties in the group portfolio include the Victoria \& Alfred Waterfront in Cape Town, Zimbali north of Durban, the Royal Livingstone and the Zambezi Sun on the Zambian side of the Victoria Falls, and the upgraded Sun City. The GrandWest Casino and Entertainment World in Cape Town reflects the magnitude of these developments. Bacon (2005) maintains that it is the group's intention to retain market leadership through innovation and an obsession with service excellence. This statement materialises in Sun International's loyalty programme, known as the "Most Valued Guest" (MVG) programme, which boasts over 600000 members. Central to the growth of the MVG programme has been the modernisation of the group with the introduction of industryleading smartcard technology (coinless gambling).

\section{Business Imperatives}

The need to adapt the gaming and casinos division's business imperatives was rated at 1.14 and responsiveness at 0.86 . The difference (GAP) of 0.28 reflected that managers felt that the division responded sufficiently. This observation is in line with the fact that Sun International maintains a leading position, which was achieved after a period of rationalisation in the late 1990s and a period of repositioning in the domestic market. In setting out to create destination alternatives with a difference, Sun International's first achievement was to secure licences in eight of South Africa's nine provinces, most notably in the East Rand, Cape Town, Durban, Bloemfontein, Polokwane and Kimberley centres. Subsequently, mass-market casinos were established in Zambia, Botswana, Namibia, Lesotho and Swaziland. This resulted in Sun International being the leading casino operator in Africa, with 19 casinos of varying sizes, and operating 23 hotels at its properties in partnership with City Lodge (Bacon, 2005). 
At its narrowest, the term 'triple bottom line' is used as a framework for measuring and reporting corporate performance against economic, social and environmental parameters. Sun International's revenue in 2005 (R5.1 billion) showed an improvement of 15\% above 2004 and 34\% above 2003 (Sun International Annual Report, 2005). Costs were well controlled and the EBITDA (earnings before interest, tax, depreciation and amortisation) margin grew by $19 \%$ to R1.7 billion, to which gambling operations contributed significantly. The improved profitability benefited shareholder returns by $6 \%$, while the return on net assets improved to $21 \%$ - five percent above 2004 . In comparing casino capitalism in South Africa and on Indian lands in California, Sallaz (2003) points out that the economic logic used by state leaders to back racial empowerment initiatives like equitable employment, affirmative procurement and black ownership promoted the transformation of the sector. In reporting on the status of BEE in the sector, the National Gambling Board of South Africa stated that BEE groups mostly play a junior or subsidiary role, and also that the lack of direct involvement in casino management does impact on their ability to service their debts from the dividends declared by the management company (National Gambling Board of South Africa, 2004). The report also indicated that all casino operators have made substantial advances in the areas of social investment, affirmative procurement, and employment equity. Central to Sun International's transformation process was the pioneering of shareholding and the management of new assets in southern Africa. New equity partnerships with black empowerment vehicles based on broad-base shareholding has created new BEE opportunities. For example, Port Elizabeth's Boardwalk casino is operated by Emfuleni resorts, which has 51\% black shareholding. In addition, the Sun International Employee Share Trust was established during 2003 to enable the group's 6200 South African employees to share in the success. Since its inception in 2003 the trust has distributed over R14 million and, in 2005, each participant benefited with R1 728 (Sun International Annual Report, 2005). A survey by the National Centre for the Study of Gambling at the University of Cape Town showed that almost $80 \%$ of all South Africans gamble at least occasionally. The report noted that the count of 550000 people in need of help to overcome gambling problems was in line with international norms (Casino City Times, 2006). Here, Sun International's sense of social responsibility is evident in its involvement in establishing the National Responsible Gambling Programme. This programme operates through the South African Responsible Gambling Trust and involves both government and the sector. The model is entirely and substantially funded by the private sector and is unique among gambling jurisdictions worldwide (Sun International Annual Report, 2005).

Sun International is considered a significant contributor to South Africa's common good. The Sun International Group Profile (2006) reports that the group distributes close to one third of the new wealth it generates to government and another third as salaries to employees. Equally important is Sun International's commitment to the international principles of sustainable development, and its leadership of the local hospitality industry's responsible tourism campaign and environmental best practice. It is also encouraging to note that the group has identified several areas for improvement, for example the need for a systematic, comprehensive reporting structure to evaluate the implementation of corporate objectives, as well as the need for rigorous feedback and tracking processes to address health, safety and environmental issues arising from internal audits. These actions are driven by Sun International's head office and are aligned to the Global Reporting Initiative guidelines included in the King II Corporate Governance Code (Sun International Annual Report, 2005).

\section{Organisational Imperatives}

The need to adapt the gaming and casinos division's organisational structure was rated at 0.52 , which was lower when compared to the previous three business innovation drivers. The actual change was noted as 0.14 , while the GAP of 0.38 reflected that managers felt that the division responded sufficiently. The perception that the face of organisations haven't changed significantly may be related to racial composition and labour conditions as approximately $80 \%$ of employees in the gaming and lotteries sector are black, $50 \%$ are female, and about $99 \%$ are permanently employed. This is the highest representation of previously disadvantaged people found in any sector in the South African tourism industry (THETA, 2003:45). This is explained by each licensee's commitment to empowerment - a condition applicable to all new gambling licences (Rogerson, 2004). White males are mostly found in senior management 
positions, whereas black females are prominently involved in marketing and sales and as game controllers and croupiers. Black female managers account for about $13 \%$ of managers in this sector, and represent about $1 \%$ of the females and $1 \%$ of the black people employed in this sector (THETA, 2003:34). This result is in line with the Human Sciences Research Council report on the general trend of overrepresentation of whites in skilled occupations and at senior management level (Moleke, 2006). THETA (2003) reports that almost all officials occupying senior management, professional, technical and associate professional occupational categories in the sector are appropriately qualified, while a number of employees of all genders and races in operative occupational categories do not have relevant qualifications.

During the 1980s, Sun International casino managers were primarily concerned with implementing growth objectives as directed by executive managers at the corporate head office. Since the year 2000 , strategic decisions have become more decentralised in view of the fact that the gaming and lotteries environment has become extremely competitive. Casino general managers are now more involved in strategic formulation, implementation and evaluation in order to maximise return on investment within their immediate business environments. An example of a more decentralised approach being followed within the group is the fact that Sun International has identified a number of priorities in taking safety, health and environmental sustainability forward within the organisation. A corporate policy has been put into place, but the objectives and targets to support its implementation will be undertaken in consultation with the individual properties. It also appears that flatter, more responsive organisational structures are being developed. Examining the breakdown of occupational categories found in the gambling and lotteries sector revealed that about $6 \%$ of all employees are in managerial and supervisory positions (THETA, 2003:27-28). This ratio of about 16 operative positions per managerial/supervisory position indicates a much more hands-off approach when compared to the 1:5 ratio reported for the accommodation sector (THETA, 2003:27-28). Departmental heads and supervisors in casinos indicated that they are encouraged to take greater responsibility for their personal development, and also that training programmes have been put in place to equip employees to exercise discretion, creativity and flare as they implement strategic decisions.

\section{Cultural Imperatives}

The mean impact of change in organisational culture was rated at 1.20, while the responsiveness of Sun International's gaming and casinos division was rated at 0.64 . The difference (GAP) of 0.56 reflected that managers agreed that the division could improve its value system and collective way of being. In reflecting on participants' comments on casino culture, two issues emerged; namely the drive for a culture of service excellence and ethics. Casino service operations centre on well-informed customers voting with their wallets. This, in turn, demands a culture of service excellence. At casino management level, line management functions have been restructured according to products and services. The improvement of marketing, sales and cost-efficiency has also been delegated to the functional units. At the casino floor level, the interface between customers and guest attendants is accentuated. Supervisors are now groomed to empower guest attendants. Overall, the organisational mindset in casino management has shifted from performing routine operational hands-on jobs, to active problem-solving and customer satisfaction while keeping the cost of service differentiation within budget.

Casino operations are subject to high-level legal compliance, and all employees are expected to commit to the highest ethical standards of conduct. Sun International's Code of Ethics addresses its reputation for openness and honesty, its moral and legal obligations, its commitment to being socially and environmentally responsible, its non-sectional and non-political support of loyalty and long-standing relationships, and its protection of the quality of its services and products (Sun International Annual Report, 2005). Furthermore, its commitment to enlightened, non-discriminatory employment policies and practices, training and skills development, and the uncontested right to organise and negotiate conditions of employment is highlighted. The group's Code of Ethics therefore confirms commitment to all stakeholders, provides guidelines governing the personal conduct of its employees, and emphasises the importance of adopting enlightened employment policies and practices. The company's board intends to enhance its Code of Ethics on a regular basis and strives to ensure that the values continue to form an 
integral part of the culture of the company. Employees who are aware of any crime, fraud or malpractice within the group may contact the group's Ethics Line on an anonymous basis. A toll-free number is manned by operators employed by an external company and is available to staff 24 hours a day. The reporting procedure is published in every edition of staff newsletters, and incidents are brought to the attention of the chief executive (Sun International Annual Report, 2005).

\section{Leader and Employee Behaviour}

The need to change leader and employee behaviour was rated at 1.22, while the responsiveness of the gaming and casinos division was rated at 0.46 resulting in a GAP of 0.76 . This difference was of similar magnitude as the GAP noted for organisational culture. Respondents' view was that this difference relates to the need to combine a sharper focus on generic business-finance issues with a sophisticated response to guest needs. This implies moving from the traditional autocratic managerial style towards team building and coaching, where success is realised through a greater number of people. Sun International shows commitment to promoting open relationships between managers and employees, for example through in-house surveys such as the 'Voice of GrandWest', which is undertaken twice per annum in major properties. Sun International states in its Annual Report (2005) that one of the goals for 2006 is to promote the attitudes and behaviour of employees by improving their safety, health and environmental knowledge within and beyond the work environment.

\section{Leader and Employee Mindset}

Of most significance was the feedback on Leader \& Employee Mindset. The mean impact of change in market requirements was rated at 1.50, while the responsiveness of Sun International's gaming and casinos division was rated as neutral with a mean of 0.00 . The difference (GAP) of 1.50 exceeded the ratings of all other transformational change drivers. In discussing their scores, employees felt that responsiveness to this driver could be improved through "strong and visible senior managers walking the floors and recognising people by their names", and that those casino leaders should "tell us where our casino is going to and how we are doing". These comments aligned to the Change Management Learning Centre Report (2006), which was based on 411 organisations' best practice in change management. The report's top reason for employee resistance to change was a lack of awareness about the change. Employees also indicated that team performance could be improved though training aimed at "growing my self-understanding", "how to deal with my work and family pressures", " how to get that sense of meaning back in my work" and "not to feel so easily threatened by age, racial and other differences". These observations relate to the comment by Salas, Burke and Wilson-Donelly (2004:300) that "effective leadership within these [multicultural] teams is a carefully leveraged balance beam. More specifically, when leaders can integrate their functional roles as sense makers with the cultural diversity within, their team's productivity is likely to be high and the experience rewarding, but when they cannot, results can be disastrous".

Workshop participants indicated that the gaming and casino division needs to improve the ability of line managers to create and sustain a vibrant organisational culture where subordinates are supported by the generation of ideas to improve their units and are backed in the implementation of solutions. This in turn will enable mid-level managers to respond to strategic issues in their business environment. Such a culture is promoted by leaders capable of shifting their mindset from individual performance to stewarding group outcomes (Caruso \& Wolfe, 2004). What also became clear is the reality that the creation of a sense of contribution and importance amongst South African employees is fraught with difficulties due to the diverse cultures found here. In reviewing leadership challenges facing South African organisations, Nkomo and Kriek (2004:91) confirm this scenario in that the black presence at top management and shop-floor levels is in sharp contrast to its presence at middle management level. This leads to frustrations on both sides of the racial divide, with talented black executives and workers feeling that transformation is too slow, and white mid-level managers being concerned about limited opportunities for promotion. A further point raised by emerging Sun International leaders was that younger generation black and white leaders are frustrated by the commanding style and some social attitudes displayed by older generation mid-level managers. In addition, they feel that leaders often direct through positional 
rather than personal power, and that management training tends to lack grounding in workplace application.

Sun International employs six leadership development programmes to address this challenge (Sun International Annual Report, 2005). Its three-day Supervisory Development Programme introduces newly promoted supervisors to the additional responsibilities of the supervisor by means of 18 supplementary modules. During 2005, a total of 806 interventions were held. The Gaming Management Development Programme was customised for neighbouring countries to meet the localisation targets required for participating countries and started at Carnival City in September 2005. The Slots Accelerated Management Programme was rolled out during 2005, and five of the delegates have already been promoted into either assistant slots manager or shift manager positions. The Graduate Management Trainee Programme is presented over a period of 18 months and aims to fast-track individuals into management positions and, at any given time, up to ten trainees are involved. During 2005, six graduates completed their programme and all were successfully integrated into the business. The Sun International Leadership Programme encourages 60 annually elected delegates to develop a strategic plan for their own growth and development within the organisation, and to develop their communication skills and confidence to interact at an executive level and to develop the values and competencies of successful leaders. The Sun International Business Leadership Programme has been integrated with all other leadership programmes and is presented annually by the University of Cape Town's Graduate School of Business to 24 delegates from across the group. This programme has been designed to enable delegates to develop a strategic view of the group and be able to manage at an operational level. In 2005 the delegates' final assessment took the form of individual presentations to the respective divisional directors and unit general managers six months after the completion of the programme.

\section{CONCLUSIONS AND RECOMMENDATIONS}

This study provides more insight into transformation in the gambling and lotteries industry. It also adds to the body of knowledge on the conceptualisation and analysis of transformation in South Africa, which is largely under-theorised and underdeveloped. In examining leader development in South Africa, Nkomo and Kriek (2004) also comment on the lack of formal reflection and inquiry as a weakness in learning about and promoting transformation in local organisations. The value of the study lies in reflecting on the transformation of South Africa's most dynamic tourism sector and the development of a methodology to monitor change within a transforming organisation.

The see-saw model proved to be a valuable tool in demonstrating that both the external and internal drivers of change must be attended to, otherwise transformational efforts will fail. The author has applied the model across industries as a reflective tool in transformational progress. In commenting on the value of the change management workshops, participants indicated that the see-saw model helped them to understand how a leader regulates the transformational flow in how he or she balances the see-saw. Too much weight on value innovation will stem the transformational flow and the end-results will be dried out. Contrarily, too much weight on fairness principles will accelerate the transformational flow to the point of disturbing the business focus. This model relates to the well-known "iceberg" metaphor where the smaller, visible part of the iceberg represents the tangible, hard-core business issues like strategic and business plans, organisational charts, systems and technology. The bulky, perilous part of the iceberg below the waterline relates to the intangible organisational elements such as people's perceptions and attitudes.

This see-saw model did pose some limitations. It was assumed that participants were well-informed and in a position to judge transformational change in their work, and furthermore that all participants were fluent in English and willing to participate and to learn. The results also provided broad data, rather than clearly showing what specifically went right or wrong. On the other hand, most valuable insight was gained though the feedback sessions. It is likely that more robust feedback can be gained by replicating this study on a larger scale and also by extending the see-saw model to a seven-point scale.

The ultimate aim of the study was to determine whether Sun International's gaming and casinos division has transformed sufficiently. Overall, employees felt that Sun International's gaming and casinos division 
responded well to business innovation. The external environment was well analysed, strategy was formalised, and the organisational structure was adapted accordingly. Change in the gambling and lotteries sector from 1970 to 1990 seemed to follow a 10-year evolutionary cycle, after which change accelerated to five-year cycles until about 2000. In the new millennium, change became evident in twoyear cycles. Employees felt, however, that customer requirements and streamlining organisational culture deserved more attention. In confirming this need to improve the balance between business innovation and fairness principles, a participant indicated that "adapting to the market as well as to human needs would do a great deal to lift the team spirit". Of most significance was the lack in transforming the leader and employee mindset, which reflects. This result reflected that a fundamental aspect of successful transformation is the development of leaders capable of balancing business opportunities and that which matters to the human soul. It may be asked whether this conclusion is a novel or a universal truth. In the 1800 s, William Wordsworth commented that when people struggle to keep their humanity during change, it leads to "dark invisible workmanship - that reconciles discordant elements - and makes them move in one society" indicating that the value of the most sophisticated strategy is nullified in the absence of people skills.

\section{ACKNOWLEDGEMENTS}

The author gratefully acknowledges the invaluable input of Mr Neville Thomson, who leads organisational development initiatives at Sun International. He conceptualises and drives hands-on transformation with persistence and courage of heroic quality.

\section{REFERENCES}

Anderson D \& Ackerman-Anderson L. 2001. Beyond change management: Advanced strategies for today's transformational leaders. San Francisco: Jossey-Bass/Pfeiffer.

Bacon P. 2005. Sun International: Chief Executive's Report [Online] Available from: www.quickreport.co.za/sun_ar_2005/ [Accessed: 12/03/2006].

Carnall C. 2006. Editorial. Journal of Change Management, 1(3):1-2.

Caruso DR \& Wolfe CJ. 2004. Emotional intelligence and leadership development. In: D.V. Day, S.J. Zacarro \& S.M. Halpin (eds.). Leader development for transforming organizations: Growing leaders for tomorrow. New Jersey: Lawrence Erlbaum Associates.

Casino City Times. 2006. South Africa gambling tax revenue up [Online] Available from: www.casinocitytimes.com/news/article.cfm?contentld=155747 [Accessed: 30/03/2006].

Change Management Learning Centre. 2006 [Online] Available from: www.changemanagement.com/best-practices-report.htm [Accessed: 12/03/2006].

Competition Tribunal Republic of South Africa. 2003. Case number: 31/LM/Jul03 [Online] Available from: www.comptrib.co.za/decidedcases/html/31LMJul03.htm.

Davis S \& Meyer C. 1998. Blur. Reading, Massachusetts: Addison-Wesley Books.

Day DV \& Halpin SM. 2004. Growing leaders for tomorrow: An introduction. In: D.V. Day, S.J. Zacarro \& S.M. Halpin (eds.). Leader development for transforming organizations: Growing leaders for tomorrow. New Jersey: Lawrence Erlbaum Associates.

Dess GG \& Pickens JC. 2000. Changing roles: Leadership in the 21st Century. Organizational Dynamics, Winter:18-33. 
Goldman I. 2000. Rural transformation in South Africa. Doctoral Thesis. Johannesburg: University of the Witwatersrand.

Goleman D. 1999. Working with emotional intelligence. London: Bloomsbury Publishing.

Grimsell C. 2005. Thirty years of hotel history and statistics: 1975-2004. Hotel \& Restaurant, August:2226.

Grulke W. 2001. Ten lessons from the future. London: Pearson Education Limited

Hamel G. 2001. Leading the revolution. Boston: Harvard Business School Press.

Hersey P \& Blanchard KH. 1993. Management of organizational behavior: Utilizing human resources. $6^{\text {th }}$ edition. New Jersey: Prentice-Hall.

Holden D. 2006. Standing in the fire. Industrial Management, 48(2):24-30.

Hull C \& Lio BH. 2006. Innovation in non-profit and for-profit organisations: Visionary, strategic and financial considerations. Journal of Change Management, 1(3):53-65.

Karp T. 2006. Transforming Organisations for organic growth: The DNA of change leadership. Journal of Change Management, 1(3):3-20.

Kim WC \& Mauborgne R. 2003. Strategy for the future: An interview with the latest hot revisionist upstarts on business strategy. The Sunday Times (Business Times). Johannesburg: Johnnic Publishing. 27 April: 7.

Matthews C. 2004. Sun's revenues rise from resorts, rates. Business Day. Johannesburg: DBFM Publishers, 1 September.

McDougall GHG \& Munro H. 1994. Scaling and attitude measurement in travel and tourism research. In: J.R.B. Ritchie \& C.R. Goeldner (eds.). Travel, tourism and hospitality research. New York: John Wiley \& Sons, Inc.

Moleke P. 2006. After ten years of employment equity, it's still business as usual. HSRC News Bulletin [Online] Available from: www.hsrc.ac.za/about/HSRCReview [Accessed: 19/03/2006].

National Gambling Board of South Africa. 2003. Economic impact of legalised gambling in South Africa [Online] Available from: www.ngb.org.za/home.asp?pid=30 [Accessed: 25/032006].

National Gambling Board of South Africa. 2004. Black Economic Empowerment (BEE) in the gambling industry [Online] Available from: www.ngb.org.za/home.asp?pid=19\&aid=27 [Accessed: 22/03/2006].

Nkomo SM \& Kriek D. 2004. Leading transformational change: Challenges and opportunities. In: T.N.A. Meyer \& I. Boninelli (eds.). Conversations in leadership: South African perspectives. Randburg: Knowledge Resources (Pty) Ltd.

Palmer M. 2005. Retail multinational learning: A case study of Tesco. International Journal of Retail and Distribution Management, 33(1):23-48.

Pearce JA \& Robinson RB. 2000. Strategic management. Singapore: McGraw-Hill Book Co.

Radebe S. 2001. R1bn later, still no sign of boom in SA tourism. Business Day. Johannesburg: DBFM Publishers, 21 September: 4. 
Rogerson CM. 2004. New directions for casino tourism in post-apartheid South Africa. In: C.M. Rogerson \& G. Visser (eds.). Tourism and development issues in contemporary South Africa. Pretoria: Africa Institute of South Africa.

Salas E, Burke CS \& Wilson-Donelly KA. 2004. Promoting effective leadership within multicultural teams: An event-based approach. In: D.V. Day, S.J. Zacarro \& S.M. Halpin (eds.). Leader development for transforming organizations: Growing leaders for tomorrow. New Jersey: Lawrence Erlbaum Associates.

Sallaz JJ. 2003. Gambling with development: The birth of casino industries in South Africa and on Indian lands in California, U.S. PhD Thesis, Department of Sociology, University of California Berkeley [Online] Available from: www.iir.berkeley.edu/culture/conference/sallaz.pdf [Accessed: 4/03/2006].

Smid G, Van Hout E \& Burger Y. 2006. Leadership in organisational change: Rules for hiring in interim management. Journal of Change Management, 1(3):3-20.

Sminia H \& Van Nistelrooij A. 2006. Strategic management and organizational development: Planned change in a public sector organisation. Journal of Change Management, 1(3):99-113.

South African Tourism. 2005. Annual Report [Online] Available from: http://www.southafrica.net [Accessed: 25/03/2006].

South African Tourism. 2006. Indaba 2006 Factsheet [Online] Available from: http://www.southafrica.net [Accessed: 30/05/2006].

STATISTICA Release 6.0. 2002. StatSoft, Tulsa, USA.

Styhre A \& Kohn K. 2006. The struggle over meaning: Rethinking the car in automotive industry. Journal of Change Management, 1(3):3-20.

Sun International Annual Report. 2005. [Online] Available from: http://www.quickreport.co.za [Accessed: 12/03/2006].

Sun International Group Profile. 2006. [Online] Available from: www.suninternational.co.za/about [Accessed: 12/03/2006].

THETA. 2003. South African Tourism, Hospitality and Sport Education and Training Authority Sectoral Skills Plan 2004-2005 [Online] Available from: www.theta.org.za [Accessed: 2/02/2006].

Van Tonder CL. 2004. Organisational change: Theory and practice. Pretoria: Van Schaik. 